\title{
ДОСЛІДЖЕННЯ ОСОБЛИВОСТЕЙ ЕКОНОМІЧНОЇ СОЦАЛІЗАЦІЇ У ЗВ'ЯЗКУ ЗІ СПЕЦИФІКОЮ СТАВЛЕННЯ СТАРШОКЛАСНИКІВ ДО ГРОШЕЙ
}

УдК: 159. 922. - 336. $67: 37$

\section{Зубіашвілі I. K.}

\begin{abstract}
Кандидат психологічних наук, стариий науковий співробітник лабораторії організаиійної та соиіальної психології Інституту психології імені Г.С. Костюка НАПН України, м. Київ (Україна)
\end{abstract}

\begin{abstract}
Анотація. $У$ статті аналізуються результати емпіричного дослідження психологічних особливостей економічної соціалізації старшокласників, розглядаються групи старшокласників за типом ставлення до грошей, виявлено типи соціальної адаптивності та рівні економічної соиіалізачії старшокласників. Економічна соціалізаџія розглядається як система взамоєпов'язаних структурних компонентів, конфігурація яких визначає особливості иього прочесу. Підкреслюється, щу психолого-економічна адаптивність є показником економічної соиіалізації особистості. Соиіальна роль грошей розглядається в контексті психолого-економічної адаптації.
\end{abstract}

Ключові слова: економічна сочіалізащія, ставлення до грошей, типи ставлення до громей, адаптація, типи адаптащіï, рівні економічної соціалізащії.

Постановка проблеми. Суттєві перетворення економічної системи українського суспільства якісно змінюють всі параметри в соціально-економічному просторі країни і окремої людини. Проблема економічної соціалізації підростаючих поколінь взагалі та становлення особистості як суб'єкта монетарних відносин, зокрема, набуває особливої актуально- сті як у теоретичному, так і практичному аспектах. Виступаючи засобом включення особистості у зв'язки з іншими учасниками економічних відносин, гроші мають безпосередній вплив на поведінку людей, на зміну їх особистісних економіко-психологічних якостей. В умовах же переорієнтації української економіки на ринкові цінності особливої актуаль- 
ності для підростаючих поколінь набуває проблема раціонального ставлення до грошей та ефективного оперування ними. Тому цілком виправданим особливий інтерес до проблеми економічної соціалізації особистості.

Аналіз останніх досліджень. Концептуальні основи вивчення проблеми економічної соціалізації представлені у наукових дослідженнях, присвячених вивченню грошей як фактору економічної соціалізації (В. Автономов, I. Андреєва, К. Девіс О. Дейнека, Д. Лассаре, Р. Тейлор, А. Фернам), особливостям ставлення до грошей на різних вікових етапах (C. Абрамова, С. Буреніна, О. Козлова, Р. Саттон, М. Семенов, Б. Стейсі, А. Стросс), ставленню до грошей як провідному компоненту економічної свідомості (О. Дейнека), закономірностям розвитку мислення в процесі засвоєння монетарних репрезентацій в різному віці (К. Данцігер, Х. Діттмар, Р. Саттон, А. Стросс, Г. Ферт), соціальнодемографічним чинникам формування монетарних уявлень у дітей (Г. Маршалл, Л. Магрудер, Р. Саттон, М. Сігал, А. Фернам, Д. Швальб).

Виклад основного матеріалу. Методологією емпіричного дослідження є інтеріндивідна парадигма, яка передбачає розуміння соціалізації як ідентифікації індивіда 3 групою, становлення соціально-економічних властивостей індивіда як члена групи.

Об'єкт дослідження: процес економі- чної соціалізації старшокласників.

Предмет дослідження: ставлення до грошей як засіб економічної соціалізації старшокласників

Мета дослідження: дослідити психологічні особливості економічної соціалізації у зв'язку зі специфікою ставлення старшокласників до грошей.

Відповідно до предмета та мети дослідження було висунуто таку гіпотезу:

На рівень економічної соціалізації старшокласників впливає тип ставлення до грошей.

Відповідно до мети і гіпотези дослідження поставлені такі основні завданнядослідження:

1. Виявити групи старшокласників за типом ставлення до грошей.

2. Визначити рівні економічної соціалізації старшокласників.

У загальну вибірку ввійшли 252 учні 10-х і 11-х класів середніх навчальних закладів, $з$ яких - 135 дівчат і 117 юнаків. Дослідження проводилось в Київській гімназії № 154, ЗОШ № 82 ім. Т. Г. Шевченка м. Києва, ЗОШ №16 ім. М. О. Кириленка м. Білої Церкви. Старшокласники, які взяли участь в дослідженні, є учнями звичайних, непрофільних класів. Рівень матеріального доходу їх родин середній.

Процес економічної соціалізації пов'язаний не тільки $з$ повсякденним життям старшокласника, але і з досить загальними соціа- 
льно-економічними проблемами. Провідна роль належить тут реальній включеності особистості в ті сфери діяльності, в яких відбувається засвоєння економічних знань і економічного досвіду.

Для здійснення емпіричного дослідження нами було розроблено програму, яка включає наступні методики.

1. Опитувальник «Ставлення до грошей» (А. Фернама).

2. «Методика виміру соціальної адаптивності» (О. Посипанова).

Опитувальник «Ставлення до грошей» (А. Фернама)[2] дозволив виявити групи старшокласників за типом ставлення до грошей.

Врезультаті факторного аналізу було виділено 5 груп (рис. 1), в яких переважають наступні типи ставлення старшокласників до грошей: «Тривожність», «Ощадливість», «Гроші - зло», «Гроші - влада», «Заробіток».

Розглянемо як на тип ставлення до грошей впливає адміністративно-територіальний чинник. Як показано на рис. 2, в результаті факторного аналізу відповідей старшокласників м. Києва нами було виділено також 5 незалежних компонент.

Порівнюючи фактори, отримані за всією вибіркою та за вибіркою по м. Києву можна визначити відмінності в отриманих факторах. У київській вибірці відсутній фактор «Заробіток», замість нього ми отримали фактор «Марнотратство». Отримані дані за цим фактором демонструють легке ставлення до грошей у досліджуваних. Таке ставлення проявляється в тому, що людина не надає грошам визначальної ролі в житті, вільно витрачає наявні грошові кошти, не проявляє особливої

\section{Рис. 1. Найбілыш вагомі фактори ставлення до грошей за всією вибіркою}

\section{(дисперсія)}

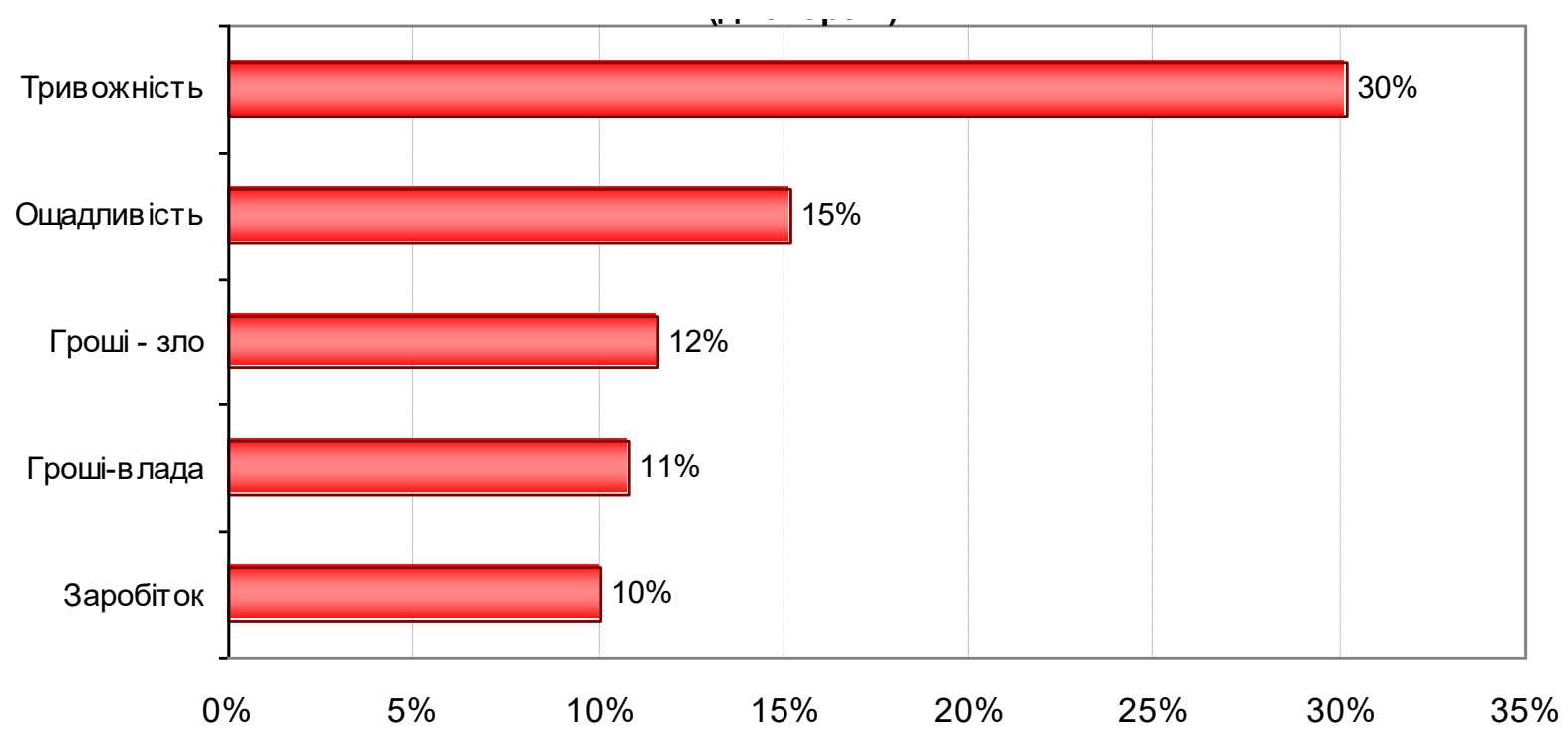


турботи про джерела їх надходження, не прагне до їх накопичення як до самоцілі. Люди, що легко ставляться до грошей, часто перетворюються на марнотратів.

Як це видно з рис. 3, в результаті факторного аналізу відповідей білоцерківських старшокласників було виділено знову ж таки 5 типів ставлення старшокласників до грошей: «Тривожність», «Гроші - влада», соціально-економічного розвитку, нестабільність ситуації в різних регіонах України обумовлюють регіональну диференціацію рівня життя населення країни. Високий рівень безробіття в регіонах примушує додавати зусилля для заробляння грошей, постійно шукати заробіток.

Ставлення до грошей старшокласників за всією вибіркою характеризується високою

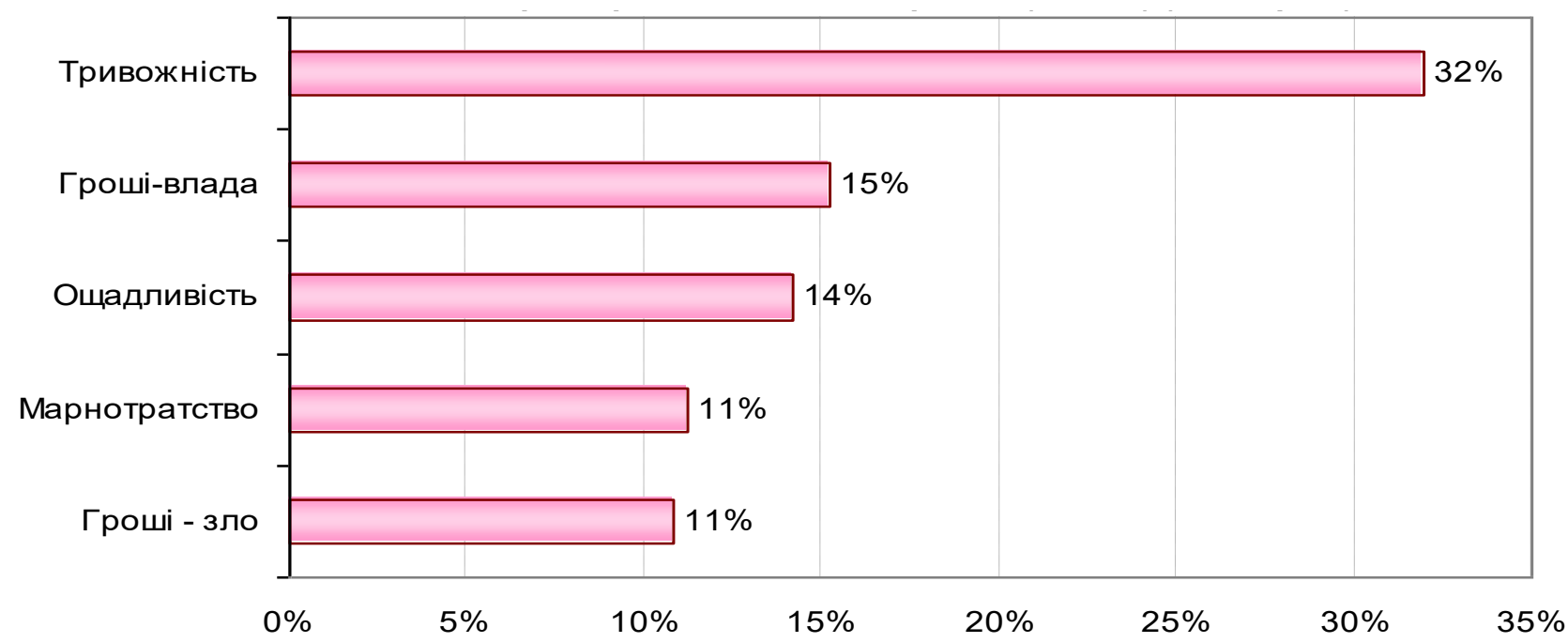

\section{Рис. 2. Найбільш вагомі фактори ставлення до грошей (м. Київ)}

«Ощадливість», «Заробіток», «Гроші - зло».

Отримані п'ять факторів виявили групи старшокласників з різним, суперечливим ставленням до грошей: досліджувані ототожнюють гроші зі злом і владою, відповідальне ставлення до грошей поєднується з марнотратством.

Отримані дані показали відсутність фактора «Марнотратство» (який був виявлено у дослідженні київських учнів), його місто зайняв фактор «Заробіток». Ці дані викликані об’єктивними обставинами. Нерівномірність афективною напруженістю, що виражається в переважанні у структурі ставлення до грошей фактору «Тривожність».

Отже, опитувальник «Ставлення до грошей» (А. Фернама) дозволив виявити групи старшокласників за типом ставлення до грошей. Слід підкреслити, що сутність економічної соціалізації в перехідний період розвитку суспільства тонко визначила О. Дейнека, означивши іiі як економіко-психологічну адаптацію. Автор має на увазі адаптацію суб'єкта го- 


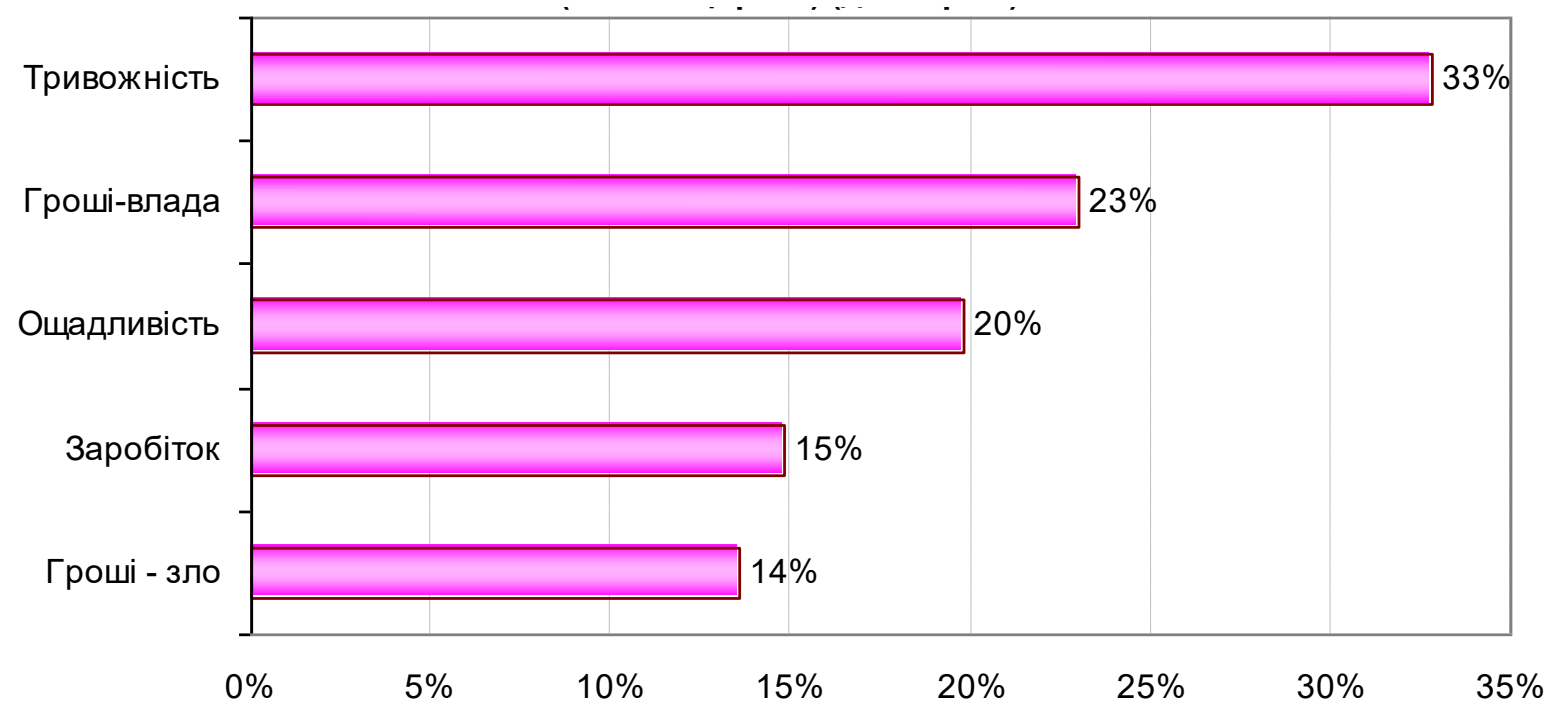

\section{Рис. 3. Найбільш вагомі фактори ставлення до грошей (м. Біла Це- рква) (дисперсія)}

сподарювання до економічних умов, що змінюються, і що проявляється в бідності або матеріальному благополуччі, тобто в економічному статусі і якості життя людини, в його очікуваннях і ставленні до економічних реформ, ринку, грошей [3].

3 метою аналізу впливу особливостей ставлення до грошей на процес економічної соціалізації старшокласників, ми провели емпіричне дослідження особливостей їх психолого-економічної адаптивності як показника економічної соціалізації.

Для виміру адаптивності старшокласників була застосована «Методикавиміру соціальної адаптивності особистості» (О. Посипанова) [6]. Уточнимо, що в нашому дослідженні адаптивність (за О. Посипановим) як здатність пристосовуватись до ціннісного середовища розглядається як показник економічної соціалізації особис- тості.

В результаті нашого дослідження (рис.

5) було виявлено, що процес соціальної адаптації у досліджуваних старшокласників проходить досить успішно, респонденти 3 низьким рівнем адаптивності («профіль» найменшої адаптивності) виявлені не були. «Профіль» конформності переважає у школярів м. Києва - 59\% (показник цього «профіля» у школярів м. Білої Церкви - 31\%, він посідає серед інших «профілей» друге місце). Цей «профіль» передбачає пасивний вид адаптації - прийняття вимог без включення процесів саморозвитку, активності. Конформна людина боїться порушити встановлену групою норму.

«Профіль» лабільності переважає у старшокласників м. Білої Церкви - 41\%. Цей «профіль» посідає у київських старшокласників друге місце - 29\% і передбачає готовність індивіда змінювати поведінку в залежності від 
ситуації, однак це відбувається за відомими стандартами і правилами.

«Профіль» креативності виявився тільки у $12 \%$ київських старшокласників та у $28 \%$ старшокласників м. Білої Церкви. Саме цей «профіль» відповідає вимогам економічної культури ринкової економіки, оскільки передбачає поведінку, яка дає можливість орієнтуватися в ситуації, що змінюється, виходити 3 кризових ситуацій.

За результатами дослідження було встановлено зв'язок між «профілями» адаптивності та факторами, отриманими за методикою «Ставлення до грошей» (А. Фернама). Ми отримали результати, що демонструють значущий кореляційний зв'язок типу ставлення до грошей і адаптивності, що дозволяє стверджувати: у сучасному суспільстві гроші виконують не тільки економічні, але і соціальні функції і є засобом економічної соціалізації підрос- таючого покоління. Отже, тип ставлення особистості до грошей впливає на процес іiї економічної соціалізації.

На основі кореляції визначених особливостей ставлення до грошей 3 «профілями» соціальної адаптивності виявлено три рівні економічної соціалізації старшокласників.

1. «Економічно-пасивний»: передбачає економічну пасивність, тривожність стосовно грошей, ефективну дію тільки в стабільній ситуації, не схильність до грошових ризиків, пасивну адаптацію в суперечливих соціальноекономічних умовах. У структурі цього рівня економічної соціалізації переважає конформність. Економічно-пасивний рівень виявлено у $59 \%$ досліджуваних старшокласників м. Києва та у $31 \%$ досліджуваних м. Білої Церкви.

2. «Економічно-активний»: передбачає

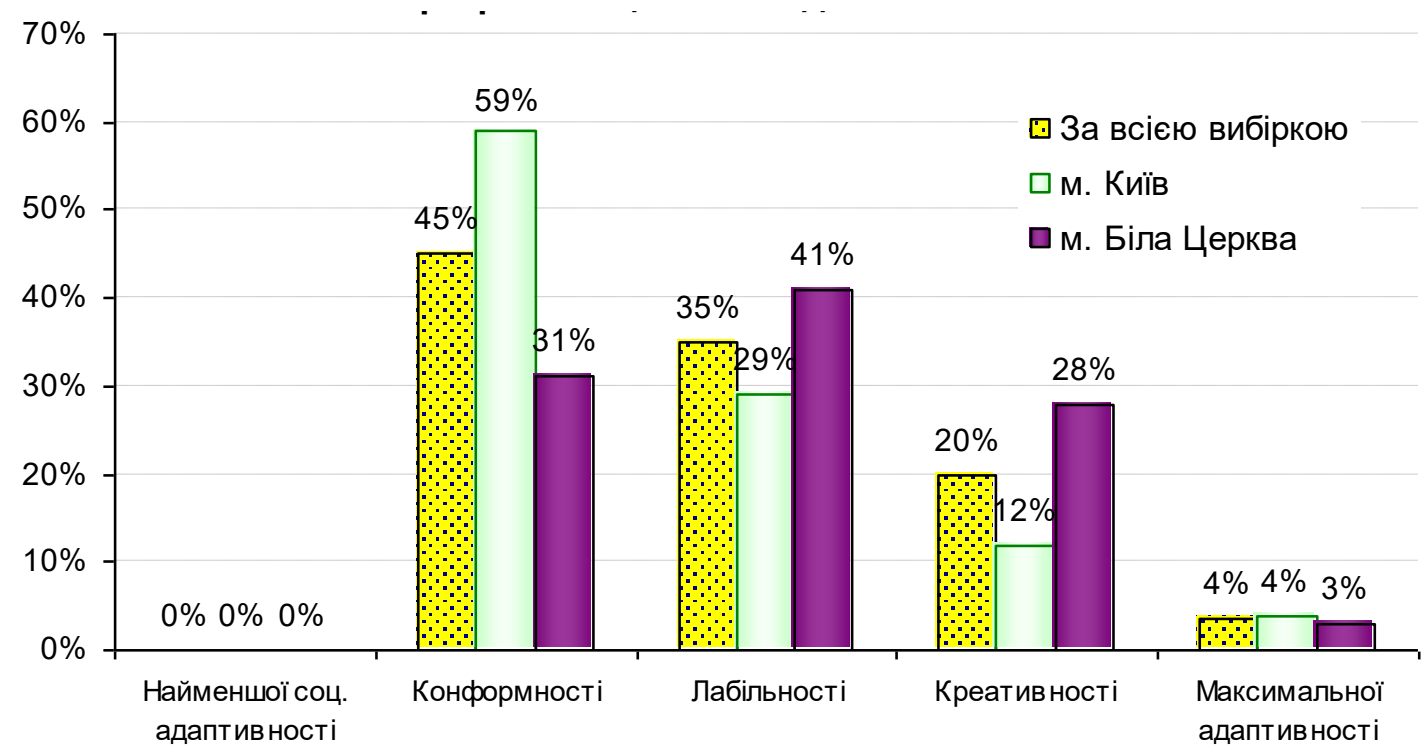

Рис. 5. «Профілі» соціальної адаптивності 
економічну активність, схильність до грошових ризиків, прийняття нестандартних рішень, не дотримування соціальних стереотипів, ефективність дій в кризових ситуаціях, успішну адаптацію в ситуації змін. В структурі цього рівня економічної соціалізації переважає креативність. Економічно-активний рівень виявлено у $12 \%$ досліджуваних старшокласників м. Києва та у 28\% досліджуваних м. Білої Церкви.

3. «Економічно-лабільний»: передбачає емоційну лабільність, ефективне використання грошей для досягнення поставленої мети, легке адаптування в нестабільній ситуації. В структурі даного рівня економічної соціалізації переважає лабільність. Ставлення до грошей у лабільних старшокласників не супроводжується тривожністю. Але за монетарною поведінкою економічно лабільної особистості можна побачити тип «марнотрата». Економічно-лабільний рівень виявлено серед $29 \%$ досліджуваних старшокласників м. Києва та у 41\% досліджуваних м. Білої Церкви.

У проблемі дослідження економічної соціалізації старшокласників важлива роль відводиться формуванню рівнів економічної соціалізації. Наше дослідження виявило перевагу економічно-активного рівня.

Висновки. Процес адаптації юнаків і дівчат до економічної ситуації в країні здійснюється на негативному емоційному фоні ставлення до грошей супроводжується тривожністю.
Визначено три рівні економічної соціалізації старшокласників : економічноактивний, економічно-пасивний, економічно лабільний. Дослідження виявило перевагу економічно-активного рівня економічної соціалізації

Аналіз взаємозв'язку ставлення старшокласників до грошей з соціальною адаптацією дозволив зробити висновок про необхідність формування економічно-активного рівня економічної соціалізації та створення програми тренінгових занять для формування цього рівня.

\section{Перелік використаних джерел:}

1. Дейнека О. С. Экономическаяпсихология : [уч. пос.]. - Спб. : Питер, изд. С. Петерб. ун-та, 2000. - 160 c.

2. Дейнека О. С. Экономическаяпсихология в российскойполитикепереходногопериода: дис....доктора психол. наук: 19.00.12 / Ольга Сергеевна Дейнека. - Спб, 1999. $-266 \mathrm{c}$

3. Дейнека О. С. Динамикаот ношенияроссийскихпредпринимателей к деньгам / Материалы 3-го Всероссийскогосъездапсихологов. - СПб., 2003, т.3. - С. 38 - 40.

4. Журавлев А. Л. Экономическоесамоопределение: т еория и эмпирическиеисследования / А. Л. Журавлев, А. Б. Купрейченко. - Изд-во «Институтпсихологии РАН», 2007. $-480 \mathrm{c}$.

6. Посыпанов нойадаптивностиличности / Современнаяпсихология: состояние и перспективы исследования. - М: ИП РАН, 2002. - Ч.2. - С. 93-112.

7. Фернам А. Деньги. Психологияденег и финансовогоповедения [пер. с англ. А. Можаева и др.]. Спб.прайм-ЕВРОЗНАК, 2005. - 352 с. 


\section{References (Transliteration):}

1. Deyneka O. S. Ekonomicheskayapsihologiya : [uch. pos.] / O. S. Deyneka. - Spb. : Piter, izd. S. Peterb. un-ta, 2000. $-160 \mathrm{~s}$.

2. Deyneka O. S. Ekonomicheskayapsihologiya v rossiyskoypolitikeperehodnogoperioda: dis....doktora psihol. nauk: 19.00.12 / Olga Sergeevna Deyneka. - Spb, 1999. $266 \mathrm{~s}$

3. Deyneka O.S. Dinamikaotnosheniyarossiyskihpredprinimateley k dengam / O. S. Deyneka // Materialyi 3-go Vserossiyskogos'ezdapsihologov. - SPb., 2003, t.3. - S. 38 40.

4. Zhuravlev A. L. Ekonomicheskoesamoopredelenie: teoriya i empiricheskieissledovaniya / A. L. Zhuravlev, A. B. Kupreychenko. - Izd-vo «Institutpsihologii RAN», 2007. $480 \mathrm{~s}$.

6. Posyipanov O. G. Metodika izmereniyasotsialnoyadaptivnostilichnosti / O. G. Posyipanov // Sovremennayapsihologiya: sostoyanie iperspektivyiissledovaniya. - M: IP RAN, 2002. - Ch.2. - S. 93-112.

7. Fernam A. Dengi. Psihologiyadeneg i finansovogopovedeniya / A. Fernam, M. Argayl; [per. s angl. A. Mozhaeva i dr.]. - Spb.praym-EVROZNAK, 2005. - 352 s.

\section{Irina Zubiashvily}

Ph.D., senior scientist, Laboratory of Organizationaland Social Psychology, G.S. Kostiuk Institute of Psychology Atthe National Academy of Educational Sciences of Ukraine.

\section{STUDY OF SPECIFIC OF ECONOMICAL SOCIALIZATION IN THE CONTEXT OF STUDENT'S RELATION TO MONEY}

\section{ABSTRACT}

In the article the problem of empirical research features of economic socialization of seniors, which is of particular relevance as the theoretical and practical aspects in terms of socioeconomic changes taking place in Ukrainian society.

It is noted that the process of economic socialization associated not only with the daily life of high school students, but also quite common socio-economic problems. The leading role here belongs to the real involvement of the individual in those areas in which there is economic assimilation of knowledge and economic experience.

Presents a program of empirical research. Result of factor analysis highlighted five groups, which are dominated by these types of seniors attitude to money: «Anxiety», «Savings», «Money - the evil», «Money - power», «Earnings».

Discovered level of social adaptation studied in high school: passive, creative, conformal, labile.

It is emphasized that the process of adaptation of young people to the economic situation in the country is carried on the negative emotional background - the attitude to money is accompanied by anxiety.

Defined three levels of economic socialization of seniors, the economically active, economically inactive, cost-labile. The study found an advantage economically active in the labor socialization

Keywords: economic socialization, attitudes to money, types of attitude to money and adaptation, types of adaptation rivniekonomichnoyi socialization. 


\section{И. К. Зубиашвили}

Кандидат психологических наук, старший научный сотрудник лаборатории организаџионной и сочииальной психологии Института психологии имени Г.С. Костюка АПН Украины, г. Киев (Украина)

\section{ИССДЕДОВАНИЕ ОСОБЕННОСТЕЙ ЭКОНОМИЧЕСКОЙ СОЦИАЛИЗАЦИИ В СВЯЗИ СО СПЕЦИФИКОЙ ОТНОШЕ- НИЯ К ДЕНЬГАМ СТАРШЕКЛАССНИ- KOB}

Аннотация. В статье анализируются результаты эмпирического исследования психологических особенностей экономической социализации старшеклассников, рассматриваются группы старшеклассников по типам отношения к деньгам, выявлены типы социальной адаптивности и урони экономической социализации старшеклассников. Экономическая соииализаци ярассматривается как система взаимосвязанных структурних компонентов, конфигурация которых определяет особенности этого процесса. Подчеркивается, что психолого-экономическая адаптивност ьявляется показателем экономической социализации личности. Социальная роль денег рассматривается в контексте психологоэкономической адаптации.

Ключевые слова: экономическая социализация, отношение к деньгам, типы отношения к деньгам, адаптация, типы адаптации, типы экономической социализации. 